\title{
"Render Innocuous the Abstraction We Fear" Johann Wolfgang Goethe in the Epochal Conflict between Scientific Knowledge and Narrative Knowing
}

Michael Böhler (Zurich)

\begin{abstract}
Within the framework of the conference the present article argues that the controversial territories Goethe every so often trespasses are not so much those between science and poetry - as often put forward, but rather a twilight zone between a traditional culture of narrative knowing and a modern culture of scientific knowledge, a distinction set forth by Lyotard (The Postmodern Condition: A Report on Knowledge, 1979). In fact, if we examine more closely the forms and means of representation Goethe uses in his dealings with scientific objects, we find that to an astonishingly high degree they exhibit the characteristics which Lyotard considers symptomatic of pre-modern "narrative knowledge", namely a mixture of various discourse functions such as savoir-faire, savoir-vivre, and savoir-écouter, with the corresponding criteria of usefulness, of justice or happiness, and of aesthetic appeal instead of the exclusive 'true'/'false' criterion of modern science discourse.
\end{abstract}

\section{Demon Abstraction}

The expression in the title quotation "... render innocuous the abstraction we fear"1 circumscribes something akin to an apotropaic act, comparable to the utterance of a spell to protect against harm. But what is the 'abstraction' whispered of here as if it were a dread calamity? Who are 'we' who fear it? And why and how must this, paradoxically, almost corporeally graspable calamity be rendered "innocuous"?

The phrase occurs in the foreword to the "Didactic Part" of Goethe's Theory of Colors. It forms the conclusion to an extended discussion of the conception and construction of the treatise. And at the same time the passage serves as an epistemological theorem stating the correlation between "pure" experience and theory-supported knowledge. It reads:

But here we must remark that, although we have adhered throughout to actual experience, and taken it throughout as our basis, yet we could not avoid stating the theoretical ideas that gave rise to the arrangement and structure of our work [this alludes to the breaking down of colors into 'physiological', 'physical', and 'chemical' categories, $M B] .^{2}$

„... die Abstraktion, vor der wir uns fürchten, unschädlich [machen].“ (Goethe, Zur Farbenlehre, 1991: 14)

2 „Hier aber ist zu bemerken, daß, ob man sich gleich überall an die Erfahrungen gehalten, sie überall zum Grunde gelegt, doch die theoretische Ansicht nicht 
Goethe continues, with a generalizing turn that acts simultaneously as a methodological critique:

Yet sometimes an extremely odd demand is made, though never met even by those who make it, namely, that experience should be presented without any theoretical bond and left to the reader or student to form by himself whatever conviction he likes. For simply to look at a thing cannot advance us. ${ }^{3}$

And now follows something that is highly typical of Goethe, characteristic of his tendency to think in transitions: a processual description of the act of cognition, which he conceives as a series of progressive transformations, perhaps even transfigurations: "Every observation passes over into contemplation, every contemplation into deliberation, every deliberation into a making of connections; so that we can say that with every attentive look at the world we are already theorizing."

To this point, we could say that Goethe is simply, by recalling its etymology, connecting the concept theory / theorize back to Plato's $\theta \varepsilon \omega p i \alpha /$ I $\varepsilon \omega \rho \varepsilon i \nu$, the contemplative gaze, and in so doing simultaneously describing, in the sequence 'observation - contemplation - deliberation - connection,' the genetic process whereby a simple instance of visual perception becomes progressively - one might say ever more spiritually - charged. Then, however, he continues:

But to do this, to carry it out with awareness, with self-knowledge, with freedom, and, to avail ourselves of a bold expression, with irony: for this, a certain dexterity is needed, if the abstraction we fear is to be rendered innocuous and the results we hope for from experience are to become truly vital and useful. ${ }^{5}$

These sentences read almost like a scientific credo in nuce accompanied by the "deliver us from [the] evil" of ominous abstraction. Yet, if we follow

verschwiegen werden konnte, welche den Anlaß zu jener Aufstellung und Anordnung gegeben." (Ibid.)

3 „Ist es doch eine höchst wunderliche Forderung, die wohl manchmal gemacht, aber auch selbst von denen, die sie machen, nicht erfüllt wird: Erfahrungen solle man ohne irgend ein theoretisches Band vortragen, und dem Leser, dem Schüler überlassen, sich selbst nach Belieben irgendeine Überzeugung zu bilden. Denn das bloße Anblicken einer Sache kann uns nicht fördern." (Ibid.)

4 „Jedes Ansehen geht über in ein Betrachten, jedes Betrachten in ein Sinnen, jedes Sinnen in ein Verknüpfen, und so kann man sagen, daß wir schon bei jedem aufmerksamen Blick in die Welt theoretisieren." (Ibid.)

5 „Dieses aber mit Bewußtsein, mit Selbstkenntnis, mit Freiheit, und um uns eines gewagten Wortes zu bedienen, mit Ironie zu tun und vorzunehmen, eine solche Gewandtheit ist nötig, wenn die Abstraktion, vor der wir uns fürchten, unschädlich, und das Erfahrungsresultat, das wir hoffen, recht lebendig und nützlich werden soll.“ (Ibid.) 
the course of the argument more closely, we find that it moves in a direction that contradicts our conventional understanding of 'abstraction.' The starting point of the discussion is, as we saw, the polemic against an empiricism of experiences juxtaposed to each other without resort to concepts or attention to context, as well as a plea for what Goethe calls a "theoretical bond." A "theoretical bond," however, can only be understood as a bundling of individual experiences under generalized concepts or categories or correlations, and so as abstraction in the usual sense.

Thus it seems here at first glance that, according to Goethe's understanding, the isolating individual experience is an abstraction, that is, a 'separating out' or 'dragging away' - in the original sense of the Latin abstractio / abstrahere - a removal from the contexts within which the experiences are situated. Hence Goethean "abstraction" seems capable of moving in two directions:

(a) Directed against an isolating, even atomizing, radical empiricism of a mere amassing of facts, it would have the negative significance of tearing the individual instance and its perception, or experience, out of the contextual whole. To prevent this a "theoretical bond" is needed. Under this aspect, the passage could be read without much difficulty as a paraphrase of the second part of Kant's dictum in the introduction to the "Idea of a Transcendental Logic" in the Critique of Pure Reason: "Thoughts without content are empty, intuitions without concepts are blind." At the same time - and this at first glance is untypical of our understanding of theory the "theoretical bond" is not purely and simply a means to the discovery of truth, to a recognition of context or the interdependence of objects, but is also a social bond or, more exactly, a pedagogical-didactical bond. For what Goethe also obviously opposes here is a procedure whereby it is left "to the reader or student to form by himself [italics $M B$ ] whatever conviction he likes." Thus the theoretical bond not only binds the observed objects to each other, it also consolidates the observing subjects, the cognoscenti and their adepts. This idea will remain important for the further course of my argument.

(b) Yet what Goethe means by that "abstraction we fear" is not just, nor even so much, the radical-empirical isolation we have just mentioned, but rather something he does not specify more precisely here in this passage and this too is typical of apotropaic speech-acts - something he rather glosses over or circumvents with "dexterity" in order to steer directly toward the "vital and useful" "results" of "experience."

6 „Gedanken ohne Inhalt sind leer, Anschauungen ohne Begriffe sind blind.“ (Kant 1968: 3, 98) 
We might note here, proleptically, that Goethe in this passage describes the act of cognition in the form of a narrative, more exactly a journey tale or even a 'quest' in the style of a courtly romance: 'observe - contemplate deliberate - connect - theorize': these are the stations or transitions of a journey from seeing to knowing. And 'awareness - self-knowledge - freedom - irony - dexterity' are the intellectual powers, faculties (or even weapons) that bring us to our goal. And if in this narrative of knowing we also wish to lift the helmet of our opponent (none other than this ominous "abstraction we fear") and assign him a face - here I condense the narrative on my part - we will find him incarnated as follows some 800 pages later in the "Materials for the History of the Theory of Colors":

[He] was a well-organized, healthy, even-tempered man, without passions, without desires. His intellect was of a constructive nature and that in the most abstract sense, so that the higher mathematics was given to him as the very faculty by which he sought to construct his inner world and master the outer. We do not presume to pass judgement on this his chief merit, and readily admit that his true talent lies beyond our scope; [...]

On the practical side, by contrast, the side of experience, he moves much closer to us. Here he enters a world with which we too are familiar and in which we are competent to judge his modus operandi as well as his success; all the more so, since it is an altogether uncontested truth that, as purely and surely as mathematics can be treated in itself, it nevertheless falls instantly into dangers at every step on the ground of experience, and - just like every other applied maxim - can lead to error, indeed make error egregious, and incur future embarrassments. ${ }^{7}$

The informed reader will have guessed that this caricature of an utterly passionless abstract-constructivist, a man without desires or perhaps

„[Er] war ein wohlorganisierter, gesunder, wohltemperierter Mann, ohne Leidenschaft, ohne Begierden. Sein Geist war konstruktiver Natur und zwar im abstraktesten Sinne; daher war die höhere Mathematik ihm als das eigentliche Organ gegeben, durch das er seine innere Welt aufzubauen und dieäußere zu gewältigen [sic! MB] suchte. Wir maßen uns über dieses sein Hauptverdienst kein Urteil an und gestehen gern zu, daß sein eigentliches Talent außer unserm Gesichtskreise liegt; [...]

Von der praktischen, von der Erfahrungsseite rückt er uns dagegen schon näher. Hier tritt er in eine Welt ein, die wir auch kennen, in der wir seine Verfahrungsart und seinen Sukzeß zu beurteilen vermögen, um so mehr, als es überhaupt eine unbestrittne Wahrheit ist, daß, so rein und sicher die Mathematik in sich selbst behandelt werden kann, sie doch auf dem Erfahrungsboden sogleich bei jedem Schritte periklitiert und ebenso gut, wie jede andere ausgeübte Maxime, zum Irrtum verleiten, ja den Irrtum ungeheuer machen und sich künftige Beschämungen vorbereiten kann." (Goethe, Zur Farbenlehre, 1991: 844-845) 
even drives, whose sole faculty for the task of comprehending the world is higher mathematics - a Polyphemus of formulas and equations - that this caricature can only be directed at Isaac Newton, Goethe's chief antagonist in color theory (Adler 1984), to whose personality he here - and this too is highly untypical - dedicates a roughly eight-page character portrait, or rather psychopathogram. It is Newton and his monomathematical broadsword that stand behind the "abstraction we fear." They are to be "rendered innocuous" with the fencing foil that is the "dexterity" of awareness, selfknowledge, freedom, and irony.

There are not a few who see Goethe as "The Man of la Mancha" in this 'quest' for true knowledge concerning light and color, see his theory of colors as a quixotism of the first order. Thus, for example, the physiologist Emil Du Bois-Reymond, who in his famous rectoral speech Goethe and No End (1883) characterized The Theory of Colors as the "stillborn dalliance of an autodidactic dilettante," 8 and believed he had uttered the final condemnation of Goethe as scientist: "From Darwinism, which with its concept of abiogenesis borders on the Kant-Laplace theory; from the emergence of man out of chaos through the mathematically determined play of atoms from eternity to eternity; from the ending of the world in ice - from these images, which our generation contemplates as unsentimentally as it has accustomed itself to the horrors of railway travel - Goethe would have turned away with a shudder."

Nor, for his part, was Goethe at a loss for obstinately defiant hyperboles when it came to "his" science, especially the Theory of Colors. Thus in one of his conversations with Friedrich Soret, the young Genevan private scholar, physicist, and numismatist, on 30 December 1823:

"But say yourself," continued he, " have I not had sufficient reason to feel proud, when for twenty years I have been forced to own to myself that the great Newton, and all mathematicians and august calculators with him, have fallen into a decided error respecting the theory of colours; and that I, amongst millions, am the only one who knows the truth on this important subject? With this feeling

8 „todtgeborene Spielerei eines autodidaktischen Dilettanten“ (Du Bois-Reymond 1883: 29).

9 „Vom Darwinismus, der durch die Urzeugung an die Kant-Laplacesche Theorie grenzt, von der Entstehung des Menschen aus dem Chaos durch das von Ewigkeit zu Ewigkeit mathematisch bestimmte Spiel der Atome, von dem eisigen Weltende - von diesen Bildern, welche unser Geschlecht so unfühlend ins Auge faßt, wie es sich an die Schrecknisse des Eisenbahnfahrens gewöhnte - hätte Goethe sich schaudernd abgewandt." (Ibid., 35) - Cf. in addition: Böhler, 'Nachwort', in Goethe 1977, 289-290. 
of superiority, it was possible for me to bear with the stupid pretensions of my opponents. People endeavoured to attack me and my theory in every way, and to render my ideas ridiculous; but, nevertheless, I rejoiced exceedingly over my completed work. All the attacks of my adversaries only serve to expose to me the weakness of mankind." - While Goethe spoke thus, with such a force and a fluency of expression as I have not the power to reproduce with perfect truth, his eyes sparkled with unusual fire; an expression of triumph was observable in them; whilst an ironical smile played upon his lips. The features of his fine countenance were more imposing than ever." (Goethe 1850: I, 109-110) ${ }^{10}$

And six years later, in a conversation with Johann Peter Eckermann on 19 February 1829, the latter reports:

During half a life he had been annoyed by the most senseless opposition on every side, and it was natural enough that he should always find himself in a sort of irritable polemic position, and be always fully armed for a passionate conflict. [...]

"As for what I have done as a poet," he would repeatedly say to me, "I take no pride in it whatever. Excellent poets have lived at the same time with myself, poets more excellent have lived before me, and others will come after me. But that in my century I am the only person who knows the truth in the difficult science of colours - of that, I say, I am not a little proud, and here I have a consciousness of a superiority to many." (Goethe 1850: II, 145) ${ }^{11}$

10 „Aber sagen Sie selbst, ' fuhr er fort, ,konnte ich nicht stolz sein, wenn ich mir seit zwanzig Jahren gestehen mußte, daß der große Newton und alle Mathematiker und erhabenen Rechner mit ihm in Bezug auf die Farbenlehre sich in einem entschiedenen Irrthum befänden, und daß ich unter Millionen der einzige sei, der in diesem großen Naturgegenstande allein das Rechte wisse? Mit diesem Gefühl der Superiorität war es mir denn möglich, die stupide Anmaßlichkeit meiner Gegner zu ertragen. Man suchte mich und meine Lehre auf alle Weise anzufeinden und meine Ideen lächerlich zu machen, aber ich hatte nichtsdestoweniger über mein vollendetes Werk eine große Freude. Alle Angriffe meiner Gegner dienten mir nur, um die Menschen in ihrer Schwäche zu sehen.' / Während Goethe so mit einer Kraft und einem Reichthum des Ausdrucks sprach, wie ich in ganzer Wahrheit wiederzugeben nicht im Stande bin, glänzten seine Augen von einem außerordentlichen Feuer. Man sah darin den Ausdruck des Triumphs, während ein ironisches Lächeln um seine Lippen spielte. Die Züge seines schönen Gesichts waren imposanter als je." (Eckermann 1868: 3. Theil, 21-22)

11 „Ein halbes Leben hindurch tönte ihm der unverständigste Widerspruch von allen Seiten entgegen, und so war es denn wohl natürlich, daß er sich immer in einer Art von gereiztem kriegerischen Zustande und zu leidenschaftlicher Opposition stets gerüstet befinden mußte. [...]

,Auf alles, was ich als Poet geleistet habe,' pflegte er wiederholt zu sagen, ,bilde ich mir gar nichts ein. Es haben treffliche Dichter mit mir gelebt, es lebten noch trefflichere vor mir, und es werden ihrer nach mir sein. Daß ich aber 
It is probably no great exaggeration on my part to claim that there is hardly a single other figure of modern European cultural history who is more of a will-o'-the-wisp than Goethe in the contiguous and overlapping zones of science and literature, poetry and knowledge, poetry as knowledge, knowledge as poetry. And the assessment of his achievements has fluctuated correspondingly wildly in subsequent scientific discourses and in the various cultural milieus. In all of this it is mostly the aspect of allocation toward one or another, or a third, category that stands in the foreground (Böhler 1984).

Of course the multiplicity of diverging appraisals of Goethe's contribution to science has to do, on the one hand, with the phenomenal breadth of his scientific interest and his prolific productivity in a broad range of disciplines such as botany, morphology, geology, meteorology, color theory, etc. (The so-called Leopoldina Edition of Goethe's writings in the area of natural science, completed just a year ago, contains 11 volumes of text and another 18 of commentary for a total of more than 16,000 pages. ${ }^{12}$ )

On the other hand, it might be a false approach from the start to speak of contiguous and overlapping zones of science and literature, poetry and knowledge, in order to grasp the phenomenon 'Goethe and the natural sciences.' For this already presumes a differentiation and systemic autonomy of knowledge- and speech-cultures that eventually had not yet cristallized, let alone become finalized, and with regard to which Goethe represented a specific type of knowledge-culture, indeed polemically championed such a type. And then it becomes problematic to seek, under such auspices of an ex post perspective, the "scientific" in the poetic works and the "poetic" in the scientific writings.

But what sort of approach should we choose to adequately describe those opaque zones of knowledge and poetry, literature and natural science, in Goethe? As is very well known, in the course of the "turn" in cultural studies of the last two decades a whole disciplinary line has developed that takes the relationship of literature and knowledge, of literature to knowledge, and of knowledge in literature as its special project and has already produced a wealth of contributions (Klausnitzer 2008; Köppe 2011; Geiger 2006), including such as relate to Goethe (Stiening 2011).

in meinem Jahrhundert in der schwierigen Wissenschaft der Farbenlehre der einzige bin, der das Rechte weiß, darauf thue ich mir etwas zugute, und ich habe daher ein Bewußtsein der Superiorität über viele.“" (Eckermann 1868: 2. Theil, 59)

12 <http://www.leopoldina.org/de/ueber-uns/akademien-und-forschungsvorhaben/ leopoldina-ausgabe-goethe-die-schriften-zur-naturwissenschaft/> [accessed $3 \mathrm{Sep}$ tember 2014] 


\section{Scientific Knowledge versus Narrative Knowledge}

In the specific context of the question of the narrativity of knowledge posed by this conference, however, I think it especially fruitful to take support from a theoretical essay that might at first glance seem rather remote from the subject. I am speaking of Jean-François Lyotard's Report on Knowledge, a commissioned report for the government of Quebec's Council of Universities which he compiled in 1979 under the title Rapport sur les problèmes $d u$ savoir dans les sociétés industrielles les plus développées, fait au Président du Conseil des Universités auprès du Gouvernement du Québec (Lyotard 1979a) and subsequently published under the better known title La condition postmoderne. Rapport sur le savoir (Lyotard 1979b; Lyotard 1984).

Lyotard's approach is fruitful because he starts with a broad concept of knowledge that is not predefined exclusively from the perspective of science, but rather includes the latter merely as a subset. ${ }^{13}$ Under 'knowledge', then, Lyotard does not simply understand an ensemble of denotative statements to be judged solely according to the 'true' / 'false' criterion in the framework of a language game among experts that has been regulated with normative precision. Instead ideas such as savoir-faire, savoir-vivre, and savoir-écouter blend into the concept savoir, with the corresponding criteria of usefulness, of justice and/or happiness (ethical sagacity), and of audial or visual beauty. ${ }^{14}$ So understood, such knowledge produces not only 'good' ('true') denotative statements, but also 'good' prescriptive as well as evaluative statements. It rests not merely on cognitive skills to the strict exclusion of others, but allows for the activity of various discourse functions: those of cognition, decision, evaluation, reformulation (à connaître, d̀ décider, $\grave{a}$ évaluer, à transformer) - one is minded of our introductory citation from Goethe. The result is that this knowledge coincides with a "formation" in the original typescript of the report for the Council of the Universities

13 «Le savoir en général ne se réduit pas à la science, ni même à la connaissance. La connaissance serait l'ensemble des énoncés dénotant ou décrivant des objets, à l'exclusion de tous autres énoncés, et susceptibles d'être déclarés vrais ou faux. La science serait un sous-ensemble de la connaissance.» (Lyotard 1979b: 36; Lyotard 1984: 18)

14 «Mais par le terme de savoir on n'entend pas seulement, tant s'en faut, un ensemble d'énoncés dénotatifs, il s'y mêle les idées de savoir-faire, de savoir-vivre, de savoirécouter, etc. Il s'agit alors d'une compétence qui excède la détermination et l'application du seul critère de la verité, et qui s'étend à celles des critères d'efficience (qualification technique), de justice et/ou de bonheur (sagesse éthique), de beauté sonore, chromatique (sensibilité auditive, visuelle), etc.» (Lyotard 1979b: 36-37; Lyotard 1984: 18-19) 
of Quebec, Lyotard explicitly added in parentheses "(German Bildung)", with the word Bildung underlined; in the book text the parenthetical reference is omitted, and the German translation of the book reads simply Bildung [English 'formation,' 'education,' 'culture'] without any allusion to Lyotard's reference to the German concept term. ${ }^{15}$ "Formation" therefore as both forma formans and forma formata - in Goethean terminology: "Minted form that lives and living grows." (Goethe 1983: 231) ${ }^{16}$

As all observers, according to Lyotard, agree, this form of traditional knowledge - and with this I come to the heart of the matter - articulates itself chiefly through use of the "account" (récit), the narrative form, so that we can speak of a veritable "narrative knowledge" (savoir narratif) as an entirely specific knowledge-culture. ${ }^{17}$ It is evident from a culturehistorical perspective that "narrative knowledge" belongs more properly to pre-modern societies - Lyotard draws his stock of examples preponderantly from ethnological sources. But at the same time he emphasizes that even modern, purely scientific knowledge requires narrative, and thus he speaks of a "return of the narrative in the non-narrative" (retour du narratif dans le non-narratif) (Lyotard 1979b: 49; Lyotard 1984: 27). Scientific knowledge, Lyotard says, is in fact dependent for its social legitimation and for its basis in what he calls "the social bond" (le lien social) on narrative knowledge or more specifically its structures of expression. For "[s]cientific knowledge cannot know and make known that it is the true knowledge without resorting to the other, narrative, kind of knowledge, which from its point of view is no knowledge at all. Without such recourse it would be in the position of

15 "Ainsi compris, le savoir est ce qui rend quelqu'un capable de proférer de «bons» énoncés dénotatifs, mais aussi de «bons" énoncés prescriptifs, de "bons» énoncés évaluatifs... Il ne consiste pas dans une compétence portante sur telle sorte d'énoncés, par exemple cognitifs, à l'exclusion des autres. Il permet au contraire de «bonnes» performances au sujet de plusieurs objets de discours: à connaître, à décider, à évaluer, à transformer... De là résulte l'un de ses principaux traits: il coïncide avec une "formation" [original typoscript of the Rapport pour le conseil des universités in parenthesis "(allemand Bildung)", (Lyotard 1979a: 26)] étendue des compétences, il est la forme unique incarnée dans un sujet que composent les diverses sortes de compétence qui le constituent.» (Lyotard 1979b: 36-37; Lyotard 1984: 18-19)

16 „Geprägte Form die lebend sich entwickelt.“ (Goethe 1988: 501)

17 «On peut dire que tous les obervateurs, quel que soit le scénario qu’ils proposent pour dramatiser et comprendre l'écart entre cet état coutumier du savoir et celui qui est le sien à l'âge des sciences, s'accordent sur un fait, la prééminence de la forme narrative dans la formulation du savoir traditionnel. [...] Le récit est la forme par excellence de ce savoir, et ceci en plusieur sens.» (Lyotard 1979b: 38; Lyotard 1984: 19) 
presupposing its own validity and would be stooping to what it condemns: begging the question, proceeding on prejudice. But does it not fall into the same trap by using narrative as its authority?" In short, this dilemma is "an endless torment". (Lyotard 1984: 29) ${ }^{18}$ And are we not reminded here of Goethe's abhorrence of "the abstraction we fear"?

\section{Legitimation and Transformation of Knowledge}

And with this return to the opening theme we come to my thesis: that the charged field in which Goethe moves is not so much that between science and poetry per se, but rather a twilight zone of conflict between the traditional culture of narrative knowledge and a modern culture of scientific knowledge. The sentence quoted in the introduction - "But to do this, to carry it out with awareness, with self-knowledge, with freedom, and [...] with irony: for this, a certain dexterity is needed, if the abstraction we fear is to be rendered innocuous and the results we hope for from experience are to become truly vital and useful" - this statement of principle would accordingly amount to nothing less than a program to transfer knowledge from a purely scientific sphere into a culture of narrative knowing. Or to say it differently, to integrate 'scientific knowledge' (savoir scientifique) into savoir-faire, savoir-vivre, savoir-écouter, thereby legitimating it within what Husserl has called the "lifeworld" (Lebenswelt).

In fact, if we examine more closely the forms and means of representation Goethe uses in his dealings with scientific objects, we find that to an astonishingly high degree they exhibit the characteristics which Lyotard considers symptomatic of "narrative knowledge." At the same time we note that it is often precisely those forms and representational means which - in the eyes of his positivistic enemies - attest to Goethe's "dilettantism". As, for instance, in the case of his provocative thesis "that the history of science is science itself": "We cannot gain a full recognition of what we possess until we have learned to recognize what others before us have possessed." 19

18 «Le savoir scientifique ne peut savoir et faire savoir qu'il est le vrai savoir sans recourir à l'autre savoir, le récit, qui est pour lui le non-savoir, faute de quoi il est obligé de se présupposer lui-même et tombe ainsi dans ce qu'il condamne, la pétition de principe, le préjugé. Mais n'y tombe-t-il pas aussi en s'autorisant du récit ? [...] C'est un tourment continuel.» (Lyotard 1979b: 51)

19 „Äußerten wir oben, daß die Geschichte des Menschen den Menschen darstelle, so läßt sich hier auch wohl behaupten, daß die Geschichte der Wissenschaft die Wissenschaft selbst sei. Man kann dasjenige, was man besitzt, nicht rein erkennen, bis man das, was andre vor uns besessen, zu erkennen weiß.“ (Goethe 1991: 16) 
The rationale that we cannot gain a full recognition of what we possess until we have learned to recognize what others before us have possessed might actually halfway accord with a (modern) science that operates according to the falsification principle; for what is acknowledged as valid knowledge requires as its dialectical background the negative transparency of a knowledge that has been pronounced surpassed. It is, however, precisely this negation of the knowledge of predecessors as science's means of forward propulsion that Goethe refuses to acknowledge, so that it comes as no surprise that in the process of explaining this idea he breaks out into a renewed tirade against Newton:

We cannot truly and honestly rejoice in the merits of our own time if we do not know how to appreciate the merits of the past. But it was not possible to write or even to prepare a history of color theory as long as the Newtonian theory held sway. For no aristocratic conceit has ever looked down with such intolerable presumption upon those who did not belong to its guild as the Newtonian school has always done in its denial of validity regarding all that was achieved before itself and was being achieved alongside it. ${ }^{20}$

According to Lyotard it is one of the four characteristics of a narrative culture of knowledge that the narrator of knowledge does not pose or understand himself as (possibly the sole) subject or emitter of this knowledge, but rather sees himself simultaneously in the role of "narratee," the hearer or receiver of a quasi collective, handed-down narrative of knowledge: "[...] the narrator's only claim to competence for telling the story is the fact that he has heard it himself. The current narratee gains potential access to the same authority simply by listening." (Lyotard 1984: 20-21)21 In Goethe it reads thus:

We have a right to demand of anyone who claims to transmit the history of any body of knowledge that he inform us how the phenomena gradually became known and what was imagined, conjectured, opined, and thought about them.

20 „Man wird sich an den Vorzügen seiner Zeit nicht wahrhaft und redlich freuen, wenn man die Vorzüge der Vergangenheit nicht zu würdigen versteht. Aber eine Geschichte der Farbenlehre zu schreiben oder auch nur vorzubereiten war unmöglich, solange die Newtonische Lehre bestand. Denn kein aristokratischer Dünkel hat jemals mit solchem unerträglichen Übermute auf diejenigen herabgesehen, die nicht zu seiner Gilde gehörten, als die Newtonische Schule von jeher über alles abgesprochen hat, was vor ihr geleistet war und neben ihr geleistet ward. (Goethe 1991: 16-17)

21 "[...] le narrateur ne prétend tirer sa compétence à raconter l'histoire que d'en avoir été l'auditeur. Le narrataire actuel, en l'écoutant, accède potentiellement à la même autorité.» (Lyotard 1979b: 39) 
To convey all this in its coherence entails great difficulties, and to write a history is always a dubious enterprise. For even with the most honest of intentions we run the risk of being dishonest, and indeed anyone who undertakes such a portrayal declares in advance that he will place much in the light and much in shadow. ${ }^{22}$

Knowledge in a narrative knowledge-culture - we can thus conclude - is the narrative of its genesis and handing-down. To this belongs the requirement - and this corresponds to the first characteristic of Lyotard's schema (Lyotard 1979b: 38; Lyotard 1984: 19-20) - that the narrative contain heroes who represent and champion the socially normative knowledgeexpertise and who are also, of course, opposed by villains. And in this perspective what else is Goethe's Theory of Color, in its text-structural and rhetorical character, than the epic of light and darkness and color with clearly distinguished figures of light as well as obscurantists.

Allow me to conclude with two last characteristics of narrative knowledgeculture as defined by Lyotard. The narrative form "[...] unlike the developed forms of the discourse of knowledge, lends itself to a great variety of language games. Denotative statements [...] easily slip in; so do deontic statements [...] Interrogative statements are implied [...] evaluative statements also enter in, etc." (Lyotard 1984: 20) A "tightly woven web" (un tissu serré), "ordered by the unified viewpoint characteristic of this kind of knowledge" (ordonnées en une perspective d'ensemble). (Lyotard 1979b: 39)

Goethe provides the example of such a language game, rather untypical of scientific texts, at the very beginning of Theory of Colors, where he first speaks of Newton and prefaces this with an intricate self-reflexive figure of speech followed by a complex allegory:

Since, however, the second part of our work [he means the polemic argument against Newtonian optics under the telling title "The Unmasking of Newton's Theory"] may appear somewhat dry in its content and perhaps too vehement and passionate in its delivery, the reader will allow us an amusing parable as

22 „Von demjenigen nun, der die Geschichte irgendeines Wissens überliefern will, können wir mit Recht verlangen, daß er uns Nachricht gebe, wie die Phänomene nach und nach bekannt geworden, was man darüber phantasiert, gewähnt, gemeint und gedacht habe. Dieses alles im Zusammenhange vorzutragen, hat große Schwierigkeiten, und eine Geschichte zu schreiben ist immer eine bedenkliche Sache. Denn bei dem redlichsten Vorsatz kommt man in Gefahr unredlich zu sein; ja wer eine solche Darstellung unternimmt erklärt zum voraus, daß er manches ins Licht, manches in Schatten setzen werde." (Goethe 1991: 17)

23 „Da aber der zweite Teil unsres Werkes seinem Inhalte nach trocken, der Ausführung nach vielleicht zu heftig und leidenschaftlich scheinen möchte, so erlaube 
a prelude to that more serious matter and as a sort of apology for the vigorous treatment alluded to. ${ }^{23}$

Yet, what Goethe calls "an amusing parable" is rather an almost Kafkaesqe allegory - casually bristling with spite and not shrinking even from sexism - of Newton's optical theory as a delapidated castle with countless added chambers that has 'grown long in the tooth' after many vendettas, yet still thinks itself a maiden and is visited by pilgrims (perhaps Goethe sees this as an example of the irony mentioned in the introductory quote).

We can observe the transformation or translation of scientific knowledge into narrative knowledge in an almost ideal - so to speak experimental - arrangement by juxtaposing and comparing Goethe's writings on the metamorphosis of plants in three states of representational aggregation: In the first place, his 1790 scientific treatise Attempt to Explain the Metamorphosis of Plants; secondly, his poem The Metamorphosis of Plants of 1798, a classical elegy in distichs; and, thirdly, his own biographical commentary in the Morphological Notebooks of 1817.

Due to time constraints I shall refrain here from a systematic differential analysis and highlight just one - yet fundamental - aspect of the poem The Metamorphosis of Plants: For here - in addition to the aforementioned three characteristics in Lyotard's "pragmatics of narrative knowledge" we find the fourth, namely "its effect on time" (son incidence sur le temps): "Narrative form follows a rhythm; it is the synthesis of meter beating time in regular periods and of accent modifying the length or amplitude of certain of those periods." (Lyotard 1979b: 41; Lyotard 1984: 21) It has at its disposal a "vibratory musical property of narrative" (propriété vibratoire et musicale) (Ibid.). Of course this relation to time is valid for all narrative forms - Lessing's Laocoon waves to us from a distance - but in the classical didactic elegy it is of course autopoietically accentuated besides. Goethe himself alludes to this in a letter to his friend Carl Ludwig von Knebel, the translator of Lucretius' De Rerum Natura, at the beginning of July 1798: "Enclosed you will find an attempt to represent the observation of nature, if not poetically, then at least rhythmically." ${ }^{4}$ The phrase "to represent the observation of nature rhythmically" is effectively the most succinct formulation imaginable for the transformation of scientific knowledge into narrative knowledge.

man uns hier ein heiteres Gleichnis, um jenen ernsteren Stoff vorzubereiten und jene lebhafte Behandlung einigermaßen zu entschuldigen." (Goethe 1991: 14-15)

24 „Beyliegend erhältst du einen Versuch das Anschauen der Natur, wo nicht poetisch doch wenigstens rhythmisch darzustellen." (Goethe 1893: IV, 13, 200) 
In the Metamorphosis of Plants this happens by virtue of the fact that an earlier somewhat dry treatise divided into 123 paragraphs, namely the Attempt to Explain the Metamorphosis of Plants, which painstakingly details the individual parts of plants and various botanical phenomena with an equally high level of rigid classificatory systematics, is converted into - better yet: set in motion by - the lively narrative of a dynamic process of becoming: textologically, so to speak, the metamorphosis of representational principles of scientific knowledge into those of narrative knowledge. The poem is situationally arranged as a garden scene, a Garden of Eden, where, however, it is not seduction that is the problem, but bewilderment with respect to the primordial chaos of a multiplicity of flowers:

Overwhelming, beloved, you find all this mixture of thousands, Riot of flowers let loose over the garden's expanse

Many names you take in, and always the last to be spoken

Drives out the one heard before, barbarous both to your ear.

All the shapes are akin and none is quite like the other;

So to a secret law surely that chorus must point,

To a sacred enigma. Dear friend, how I wish I were able

All at once to pass on, happy, the word that unlocks!

Growing consider the plant and see how by gradual phases

Slowly evolved, it forms, rises to blossom and fruit.

(Goethe 1983: 155) ${ }^{25}$

And now over the remainder of the eighty-verse poem plays one of those films that depict in time-lapse or fast motion a morphogenetic process that in reality elapses very slowly, all interspersed with commentary, inferences, moral lore, similes etc. - in Lyotard's terminology, with denotative statements as well as deontic, interrogative, and evaluative statements belonging to the realm of savoir-faire, savoir-vivre, and savoir-écouter - all in all, with language games typical of narrative knowing.

"Growing consider the plant": In this phrase - as one may say without great exaggeration - Goethe's whole program, "to represent the observation of nature rhythmically," is fully expressed in nuce, and with the hexametric

25 „Dich verwirret, Geliebte, die tausendfältige Mischung / Dieses Blumengewühls über den Garten umher; / Viele Namen hörest du an, und immer verdränget / Mit barbarischem Klang einer den andern im Ohr. / Alle Gestalten sind ähnlich, und keine gleichet der andern; / Und so deutet das Chor auf ein geheimes Gesetz, / Auf ein heiliges Rätsel. O könnt' ich dir, liebliche Freundin, / Überliefern sogleich glücklich das lösende Wort! / Werdend betrachte sie nun, wie nach und nach sich die Pflanze, / Stufenweise geführt, bilde zu Blüten und Frucht." (Goethe 1987: 420-421) 
flow of elegiac distichs it likewise accords with Lyotard's stipulation of the "vibratory musical property of narrative." The metrically induced inversion of the regular German prose word order is also very striking syntactically: The strongly accented "growing" (werdend) placed at the head of the hexameter is at first glance clearly connected contentually with the described object "plant" (and it is usually translated so, monosemically). But "growing" can also - understood adverbially with the imperative "consider" (betrachte) - be applied to the addressed beloved in the process of considering and listening/reading. And finally, "growing" describes the progressive unfolding of the elegiac narrative. Thus we have a tripartite morphogenesis: a) of the described object, b) of the considering listener/reader, c) of the narrative text. Together they make up a morphogenetic ispòs $\gamma \dot{\alpha} \mu \circ$ (sacred $^{\prime}$ marriage), something Goethe alludes to toward the end of the poem:

In a circular cluster, all counted and yet without number,

Smaller leaves take their place, next to a similar leaf.

Pushed close up to the hub now, the harbouring calyx develops

Which to the highest of forms rises in colourful crowns.

Thus in fulness of being does Nature now glory, resplendent,

Limb to limb having joined, all her gradations displayed.

Time after time you wonder [...] (p. 157)

[...]

And how Amor at last blessed it with blossom and fruit.

Think how variously Nature, the quietly forming, unfolding,

Lent to our feelings now this, now that so different mode!

Also rejoice in this day. Because love, our holiest blessing,

Looks for the consummate fruit, marriage of minds, in the end,

One perception of things, that together, concerted in seeing,

Both to the higher world, truly conjoined, find their way.

(Goethe 1983: 159) ${ }^{26}$

In complete accord with Lyotard's thesis, the text also generates a lien social, a social bond, in its narrative process, and does so in growing rings: As

26 „[... Rings im Kreise stellet sich nun, gezählet und ohne / Zahl, das kleinere Blatt neben dem ähnlichen hin. / Um die Achse gedrängt entscheidet der bergende Kelch sich, / Der zur höchsten Gestalt farbige Kronen entläßt. / Also prangt die Natur in hoher, voller Erscheinung, / Und sie zeiget, gereiht, Glieder an Glieder gestuft. / Immer staunst du aufs neue [...][...] Und wie Amor zuletzt Blüten und Früchte gezeugt. / Denke, wie mannigfach bald die, bald jene Gestalten, / Still entfaltend, Natur unsern Gefühlen geliehn! / Freue dich auch des heutigen Tags! Die heilige Liebe / Strebt zu der höchsten Frucht gleicher Gesinnungen auf, / Gleicher Ansicht der Dinge damit in harmonischem Anschaun / Sich verbinde das Paar, finde die höhere Welt." (Goethe 1987: 422-423) 
nucleus, the love bond between speaker and listener, which is thematized in the poem itself and later on referred to in the biographical notes to the Morphological Notebooks: "This poem was highly welcome to the actual beloved who had the right to refer the sweet images to herself; and I too felt very happy when the vivid parable increased and completed our beautiful, perfect affection." ${ }^{27}$ Then there is the bond of the fairly narrow circle Goethe calls upon in the same passage, where he off-handedly dashes off a small Kulturphilosophie with respect to science and poetry and juxtaposes the "abstract [! $M B]$ gardening" of his botanical research to an aesthetics of horticulture:

I heard similar strains from other quarters; no one anywhere would allow that science and poetry could be united. They forgot that science had developed out of poetry and did not consider that with a shift in the times the two might well meet as friends again, to mutual advantage, on a higher level.

Lady friends who already on earlier occasions would gladly have drawn me from the lonely mountains and the contemplation of rigid crags were by no means content with my abstract gardening either. Plants and flowers should stand out in form, color, and scent, yet now they vanished to a ghostly silhouette. And so I tried to entice these benevolent minds to sympathy by means of an elegy, which may be granted a place here, where in the context of scientific presentation it might become more intelligible than if it were inserted in a series of tender and passionate poems. [The poem follows, $M B$. ] $^{28}$

- - And beyond this, we too, as willing readers, are ultimately included in the growing rings, brought into the association of the "social bond."

27 „Höchst willkommen war dieses Gedicht der eigentlich Geliebten, welche das Recht hatte, die lieblichen Bilder auf sich zu beziehen; und auch ich fühlte mich sehr glücklich, als das lebendige Gleichnis unsere schöne vollkommene Neigung steigerte und vollendete." (Goethe 1987: 423)

28 „Von andern Seiten her vernahm ich ähnliche Klänge, nirgends wollte man zugeben, daß Wissenschaft und Poesie vereinbar seien. Man vergaß, daß Wissenschaft sich aus Poesie entwickelt habe, man bedachte nicht, daß, nach einem Umschwung von Zeiten, beide sich wieder freundlich, zu beiderseitigem Vorteil, auf höherer Stelle, gar wohl wieder begegnen könnten. / Freundinnen, welche mich schon früher den einsamen Gebirgen, der Betrachtung starrer Felsen gern entzogen hätten, waren auch mit meiner abstrakten Gärtnerei keineswegs zufrieden. Pflanzen und Blumen sollten sich durch Gestalt, Farbe, Geruch auszeichnen, nun verschwanden sie aber zu einem gespensterhaften Schemen. Da versuchte ich diese wohlwollenden Gemüter zur Teilnahme durch eine Elegie zu locken, der ein Platz hier gegönnt sein möge, wo sie, im Zusammenhang wissenschaftlicher Darstellung, verständlicher werden dürfte, als eingeschaltet in eine Folge zärtlicher und leidenschaftlicher Poesien." (Goethe 1987: 420) 
Thus the "theoretical bond" in the observation of nature that we took as our starting point in the title passage here becomes the rhythmical bond of bound language, which as "social bond" incorporates the beloved and Goethe's lady friends, put in an ill humor by his "abstract gardening," and hopefully ourselves as well through my own gardening.

(Transl.: Robert E. Goodwin, Skidmore College)

\section{References}

Adler, Jeremy D. (1984): 'Goethe und Newton: Ansätze zu einer Neuorientierung am Beispiel der chemischen Verwandtschaft', in Goethe im Kontext: Kunst und Humanität, Naturwissenschaft und Politik von der Aufklärung bis zur Restauration, ed. by Wolfgang Wittkowski (Tübingen: Niemeyer Verlag), pp. 300-309.

Böhler, Michael (1984): 'Naturwissenschaft und Dichtung bei Goethe', in Goethe im Kontext: Kunst und Humanität, Naturwissenschaft und Politik von der Aufklärung bis zur Restauration, ed. by Wolfgang Wittkowski (Tübingen: Niemeyer Verlag), pp. 313-335.

Du Bois-Reymond, Emil Heinrich (1883): Goethe und kein Ende. Rede (Leipzig: Verlag von Veit \& Comp.) <http://archive.org/details/ goetheundkeinend00dubouoft $>$ [accessed 3 September 2014]

Eckermann, Johann Peter (1868): Gespräche mit Goethe in den letzten Jahren seines Lebens, in drei Theilen, $3^{\text {rd }}$ ed. (Leipzig: F. A. Brockhaus).

Geiger, Daniel (2006): Wissen und Narration. Der Kern des Wissensmanagements (Berlin: Erich Schmidt).

Goethe, Johann Wolfgang von (1850): Conversations of Goethe with Eckermann and Soret, transl. by John Oxenford, 2 vols (London: Smith, Elder and Co.)

- (1893): Briefe, in Goethes Werke, Herausgegeben im Auftrag der Großherzogin Sophie von Sachsen (Weimar: Hermann Böhlau), IV. Abteilung, vol. 13.

- (1977): Schriften zur Naturwissenschaft, ed. by Michael Böhler (Stuttgart: Philipp Reclam).

- (1983): Selected poems, ed. by Christopher Middleton, transl. by Michael Hamburger (Cambridge, Mass.: Suhrkamp/Insel Publishers Boston).

- (1987): Schriften zur Morphologie, ed. by Dorothea Kuhn, in Sämtliche Werke. Briefe, Tagebücher und Gespräche (Frankfurt a. M.: Deutscher Klassiker Verlag), I. Abteilung, vol. 24. 
- (1988): Gedichte 1800-1832, ed. by Karl Eibl, in Sämtliche Werke. Briefe, Tagebücher und Gespräche (Frankfurt a. M.: Deutscher Klassiker Verlag), I. Abteilung, vol. 2.

- (1991): Zur Farbenlehre, ed. by Manfred Wenzel, in Sämtliche Werke. Briefe, Tagebücher und Gespräche (Frankfurt a. M.: Deutscher Klassiker Verlag), I. Abteilung, vol. 23/1.

Kant, Immanuel (1968): Kritik der reinen Vernunft, in Werke in zehn Bänden, ed. by Wilhelm Weischedel (Darmstadt: Wissenschaftliche Buchgesellschaft), vol. 3 .

Klausnitzer, Ralf, ed. (2008): Literatur und Wissen. Zugänge - ModelleAnalysen, De Gruyter-Studienbuch (Berlin: De Gruyter).

Köppe, Tilmann, ed. (2011): Literatur und Wissen. Theoretisch-methodische Zugänge, Linguae \& litterae, 4 (Berlin: De Gruyter).

Lyotard, Jean-François (1979a): Rapport sur les problèmes du savoir dans les sociétés industrielles les plus développées, fait au Président $d u$ Conseil des Universités auprès du Gouvernement du Québec. <http://www.cse.gouv. qc.ca/fichiers/documents/publications/ConseilUniversite/56-1014.pdf> [accessed 3 September 2014]

- (1979b): La condition postmoderne. Rapport sur le savoir, Collection «Critique», (Paris: Les éditions de minuit).

- (1984): The Postmodern Condition: A Report on Knowledge, transl. from the French by Geoff Bennington and Brian Massumi, Theory and History of Literature, 10 (Minneapolis: University of Minnesota Press).

- (1999): Das postmoderne Wissen. Ein Bericht, transl. from the French by Otto Pfersmann, $4^{\text {th }}$ ed. (Wien: Passagen Verlag).

Stiening, Gideon (2011): “Und das Ganze belebt, so wie das Einzelne, sei”: Zum Verhältnis von Wissen und Literatur am Beispiel von Goethes "Die Metamorphose der Pflanzen", in Literatur und Wissen: Theoretischmethodische Zugänge, ed. by Tilmann Köppe, Linguae \& litterae, 4, (Berlin: De Gruyter), pp. 192-213. 